人，新井隆広，村上幸人，山口千美，平野美和，富永 登志，西村洋司（三井記念） 1985年より1990年まで に当科を受診した腎細胞癌75症例について検討した。 平均年齢は62歳男性は女性の約 2.5 倍. 症状を呈し当科 を受診したのは36例48\%であった。これに対し健診, 他疾患の経過観察中に偶然発見された症例は 39 例 $52 \%$ であった。この中には他の癌観察中の 7 例も含まれて い九. TNM 分類では, pT2b が53\%, Robson 分類で は Stage I が48\%と全体的に早期例が多かった。全症 例の 5 生率は $79 \%$ と既報告より高くこれは再発率が Stage IはII，IIIより有意差をもって低く，生存率も Stage I はIII, IVに比べ有意に高いこと, 及び当科にお い大多い偶然発見例が，有意に早期癌及び生存率が高 いむとのためと思われた。このことは健診等での画像 診断能力の向上が大きいと思われた。

零癌116例の臨床的検討：長谷川道彦, 吉田直人, 石 倉功一, 野村一雄, 岡本知士, 丹治 進, 小池博之,

藤岡知昭, 久保 隆（岩手医科大）当施設にお打る 腎癌128例につきその臨床像を明らかにし, 治療成績等 の臨床結果を検討した。対象は1980年 1 月から1991年 6 月までに腎癌と診断された128例で103例は病理組織 学的に診断し，25例は手術非施行例で臨床的に診断し た.これらの症例の性：年齢別頻度, 主訴の推移, Robson 分類, TNMV 分類, 手術方法等の分布頻度を示し た。 また，手術非施行例を含めた全例について主訴， 病期，遠隔転移の有無に関する生存率を比較検討した。 手術施行例については, 手術法, 到達法, リンパ節郭 清の有無, 病理組織学的所見汇関寸る生存率を比較検 討し報告した。生存率で主訴, 病期（Robson： TNMV), 遠隔転移, 異型度別き関して有意差を認め た.

\section{堅血管筋脂肪腫16例の臨床的検討：藤城徹幸, 横山} 正末, 金村三樹郎, 北原 研, 福庭雅洋, 小田裕之, 殿谷 栄(虎の門) 性別は男 7 例, 女 9 例。年齢は $35-67$ 歳(平均 50.0 歳). 患側は右 10 例, 左 5 例, 両側 1 例. 腫瘍径 (CT 測定値) は5 111mm（平均 $25.1 \pm$ $24.7 \mathrm{~mm}$ ) であった。診断後，1例（径 $32.0 \mathrm{~mm}$ ）訬 細胞癌との鑑別が困難であり腎摘除術を施行. 4 例(径 $24,25,38,111 \mathrm{~mm})$ は腫瘍破裂による重篤な出血が 危惧されたため無症状であったが腎部分切除術を施 行. 経過観察中（術後 $29 ， 38 ， 6 ， 15$ 力月）再発を認 めず， 1 例に患側腎の軽度機能障害を認めた。また11 例（径5 37mm, 平均 $16.4 \pm 10.9 \mathrm{~mm}$ ) は経過観察を 行い, 観察中（平均 26.7 月）腫崵の増大を認めたの
は 1 例のみであった。我々は，無症状かっ径 $20 \mathrm{~mm}$ 未 満の小腫瘍は超音波, CT, MRI 等に上る経過観察を行 い，症状を有する場合や径 $20 \mathrm{~mm}$ 以上の腫瘍は観察を 厳重に行らか，或いは腎部分切除術等行ら方針として いる。

長期血液透析患者に併発した堅㾰の 5 症例：吉本 充, 田中 宽, 竹垣嘉訓, 沢村 新, 韓 栄新（大野 記念), 前川正信, 岸本武利 (大阪市立) 過去 6 年 3 カ月間で血液透析患者543名のうち5例に腎癌を経験 しすべてに手術を施行した。全例が男性で年齢は31歳 から 54 歳, 平均 43 歳。透析歴は, 4 年 3 力月から 10 年 1 力月, 平均 7 年 2 カ月と長期であった。原発患は, 慢性系球体腎炎を 3 例, ネフローゼ玨候群 1 例, 囊胞 腎（PCK） 1 例であったテ右 2 例, 左 3 例で病理組織 は全例が, Renal cell carcinoma, clear cell type で, 前 4 例は，多囊胞化萎縮腎に合併した腎癌であった。 当院における腎癌の発生率は, $0.9 \%$ あったた。透析患 者の腎癌発生率は，一般人と比べて約 40 倍之高率であ り，CT-scan や超音波検査による定期的なスクリー ングが必要である。京た PCKに合佯した腎癌の 1 症 例は，本邦第17番目の報告であった。

腎細胞癌の組織学的所見と予後: 非坂茂夫, 岡野達 弥, 富岡 進, 島崎 淳 (千葉大), 江十嵐辰男, 村上 信乃 (旭中央)，松葶 理 (千葉県がんセンター病理) 目的：腎細胞癌の病理組織学的所見の予後に及ぼす影 響を解析し，現在用いられている分類法の問題点につ いて検討した。対象と方法：過去30年間に腎摘除術を 行った腎細胞癌372例を対象として, 摘出標本から得ら れる組織学的情報と予後（癌死の及を死亡とした Cause specific survival) との関係を行析した。結果： T1の境界值は最大径 $3 \mathrm{~cm}$ に設定するのが適切と考兄 られた。 T3の規定に関して，被膜外浸潤之静脈浸潤は それぞれ予後因子となるので, T3a と T3b に細分類す る意義を認めた。静脈浸潤はV1aを含めて重要であ り，V因子として記載する必要がある。腎孟浸潤は単 独の因子としては意義を認めなかった。

UICC の Stage 分類法に基つく腎病560例の予後の 検討：中橋 満(県立足柄上), 里見佳昭(横須賀共済), 穂坂正彦 (横浜市立大), 近藤猪一郎, 吉邑貞夫, 福島 修司, 井田時雄, 広川 信, 古畑哲庐, 熊谷治已, 塩 崎 洋, 石塚栄一, 宮井啓国, 福岡 洋, 佐々木紘一, 公平昭男, 仙賀 裕, 福田百邦, 岸昍 健 (横浜市立 大腎癌研究グループ） 横浜市大招云び関連病院にお ける腎癌560例を集計し, UICC の Stage 分類法に基づ 